\title{
Inter-organizational Cooperation as part of Open Innovation
}

\author{
Joanna ZIMMER ${ }^{1}$, Katarzyna WALECKA-JANKOWSKA ${ }^{2}$ and \\ Dominika MIERZWA ${ }^{3}$
}

\author{
${ }^{1,2}$ Faculty of Computer Science and Management, Wroclaw University of Science and Technology, 27 \\ Wybrzeże Wyspiańskiego st. 50-370 Wroclaw, Poland \\ ${ }^{3}$ Faculty of Management, General Tadeusz Kościuszko Military University of Land Forces, 109 \\ Czajkowskiego st. 51-147 Wrocław, Poland
}

Correspondence should be addressed to: Joanna Zimmer; joanna.zimmer@pwr.edu.pl

Received date: 8 September 2018; Accepted date: 16 December 2018; Published date: 25 April 2019

Academic Editor: Gratiela Dana Boca

Copyright (C) 2019. Joanna ZIMMER, Katarzyna WALECKA-JANKOWSKA and Dominika MIERZWA.

Distributed under Creative Commons CC-BY 4.0

\begin{abstract}
Innovation occupies an important place among factors determining the competitiveness of enterprises. In the context of turbulent environment, research on enterprise innovation emphasizes the fact that innovation processes can no longer focus only on internal knowledge. Innovative processes of modern enterprises are increasingly open to external knowledge or technology. This knowledge is often acquired on the basis of cooperation between the organizations. Involving external entities not only as observers but primarily as participants in the process of innovation at each of its stages contributes to the opening of organization boundaries. The purpose of the article will be to present inter-organizational relations established by organizations applying the concept of open innovation on the Polish market. Research on a sample of 105 innovative enterprises was conducted through a questionnaire survey. The questionnaire was developed based on a 5-point Likert scale. The aim of the study was to determine the type of relations, among others, in terms of their width and depth and measures used in the studies of Chesbrough, Vanhaverbeke and West; 2006).
\end{abstract}

Keywords: inter-organizational cooperation, open innovation, relations, management.

Cite this Article as: Joanna ZIMMER, Katarzyna WALECKA-JANKOWSKA and Dominika MIERZWA (2019)," Inter-organizational Cooperation as part of Open Innovation ", Journal of Innovation \& Business Best Practice, Vol. 2019 (2019), Article ID 729117, DOI: 10.5171/2019.729117 


\section{Introduction}

Dynamic market changes and the resulting growth of consumers demand are the cause of establishing and building interorganizational relations which is extremely important for modern organizations (Zakrzewska-Bielawska, 2016). Networks provide access to resources similar to capital (Najafian and Colabi, 2014), power and influence (Sousa, et .al., 2018), which enable gaining a competitive advantage and development (Wojciechowski, 2018). Organizations need different relations to acquire access to knowledge and investors (Aldrich and Martinez, 2018). Cooperation within inter-organizational networks is conducive to the development of new products (Karamanos, 2012, Mazzola, et al., 2015; Soh, 2003), creating knowledge (Mazzola, et al., 2015) and raising financial performance by reducing costs and time of innovation (Chesbrough and Vanhaverbeke, 2006; Sousa, et al., 2018).

Inter-organizational relations are of particular importance for organizations aiming at opening the innovative processes to streams of knowledge or technologies from outside, due to, among others, cooperation with competitors, clients, suppliers and communities (Wojciechowski, 2018). Involving external entities not only as observers but primarily as participants in the process of innovation, at each of its stages, forces the co-creation of innovations (Pallot, et al., 2010) and contributes to the opening of organization boundaries (Bogers et.al., 2016). Combining acquired external knowledge with knowledge developed internally and bringing in-house inventions to markets via external paths (Dahlander and Gann, 2010) distinguishes the concept of open innovation from the traditional, closed model of generating innovation. Closed innovation processes include strong protection of knowledge and technology developed internally and they also require high expenditure on innovation. This causes a situation in which inventions are implemented on the market mainly by large organizations, and the process of developing and diffusing innovations is usually a long-term one. Despite these considerable efforts in the innovative process, organizations may not be successful due to the pace of market changes and competition. In addition, different types of innovation may require different types of knowledge and degrees of involvement of external sources to develop them.

The increase in interest in the open approach to innovation, observed in the world, causes the question to arise: are organizations operating on the Polish market willing to open their innovation processes? If so, what kind of relation is common for them? The aim of the study will be to present inter-organizational relations established by organizations applying the concept of open innovation on the Polish market.

\section{The Importance of inter-organizational Relations for Open Innovations}

Establishing inter-organizational relations results from the desire to obtain resources that the organization does not have at the moment (Stańczyk-Hugiet, 2013). Properly used resources, whether tangible or intangible, may determine the competitive advantage on the market. Due to relations with others, organizations gain better access to knowledge or markets. E. Stańczyk-Hugiet (2013), notes that in the inter-organizational relations, the process of deleting resources, which are currently not used by organization, is very important. That is because as the result, they become available outside the organization in a paid way or not (Stańczyk-Hugiet, 2013).

According to J. Fauludi (2014), relation networks among organizations with open innovation processes can be classified due to their repose (Faludi, 2014): 
- Cooperation in the field of innovation;

- $\quad$ Sharing knowledge;

- Transforming the boundaries of organization;

- Collaboration;

Research shows that organizations cooperate in constructing innovation networks that enable the sharing of knowledge, technology or ideas (Chesbrough and Crowther, 2006). In the literature, there is no unambiguous identification of organizations (due to their size, age, industry or intensity of their own R\&D processes), which are more likely to cooperate in the field of innovation. A. Barge-Gil (2010) believes that such cooperation is more important for smaller organizations operating in sectors with low or medium technological advancement (Barge-Gil, 2010). This is due to the fact that small enterprises have limited resources necessary to develop innovations but want to remain competitive. External knowledge can become a strategic resource for them which will enable the implementation of complex projects with a high degree of risk (Barge-Gil, 2010). The pace of development of the sector in which it operates enterprise may also be important. The knowledge bases in the lowtech sector are very distributed and innovation performance in this sector is highly dependent on the knowledge coming from high-tech industries (Barge-Gil, 2010). However, a study by P. De Faria et al., (2010), suggests that it is more important for organizations with intensive R\&D activities, operating in high-tech sectors (De Faria et al., 2010). Enterprises with more resources may devote some of their resources to cooperation activities. It should be noted that radical innovations are highly revolutionary in nature, while incremental innovations focus on refining existing firm offerings by reinforcing prevailing firm capabilities (Obal, et al., 2016). Therefore, radical innovations require multiple sources of external knowledge but with high quality of cooperation (deep cooperation). In contrast, incremental innovations will be generated based on specific information, from many sources, enabling better matching of the offer to the market (wide cooperation).

Transfer of knowledge and technology is carried out using the innovation network. In the concept of open innovation, organizations acquire external knowledge from various entities (customers, contractors, R \& D units, competitors, etc.), and make it available on the market, for a fee or through other agreements. Success in generating innovation depends on the nature of the cooperation partners (De Faria et al., 2010). Vertical spillovers, associated with suppliers and customers, have a more significant effect on $R \& D$ performance and welfare than horizontal spillovers linked to universities, research institutes and competitors (De Faria et al., 2010).

In addition, enterprises that are more effective in appropriating the results from their innovation processes are also more likely to cooperate in R\&D (De Faria et al., 2010). Sharing knowledge between organizations is related to the absorption of knowledge. Lack of absorption capacity in the organization is a barrier for seeking and acquiring external knowledge (Cohen and Levinthal, 1990; De Faria et al., 2010).

Large organizations usually have broader opportunities to absorb knowledge but less demand for external sources, while smaller organizations have a greater need for external knowledge, but much weaker opportunities to absorb knowledge from outside (Barge-Gil, 2010; De Faria et al., 2010). Literature in the field of innovation indicates that radical innovations will be more often developed with the help of universities and public and private research institutions (De Faria et al., 2010; Bercovitz and Feldman, 2007), that help define new paths of products and services development (Bercovitz and Feldman, 2007). Such cooperation is the domain of large enterprises that patent and/or receive public funding for innovation since these firms have more resources to invest in 
research that does not have an immediate market orientation (Fontana et al., 2006).

Relations related to the exchange of knowledge and cooperation in the field of innovation contribute to the transformation of organization boundaries (they are no longer so tight). In particular, the role of employees the $\mathrm{R}$ \& D department must go far beyond the boundaries of the enterprise (Chesbrough, 2003). A central contingency on this level lies in the interface between the collaboration that involves knowledge flows across organizational boundaries and the value creation and capture process that is implied in the business model (Bogers et.al., 2016).

In addition, a significant increase in the number and mobility of knowledge workers results in difficulties in the control of their knowledge and ideas (Chesbrough, 2003), which causes the innovation process to disperse. Both radical and incremental innovations (in line with the Open Innovation concept) require the transformation of enterprise boundaries.

Collaboration in the case of open innovations will primarily concern the development of open resources and the open source using the user community, platforms, cooperation between competing organizations and building networks between sectors to increase profit (Mazzola, et al., 2015). An open collaborative innovation project involves contributors who share the work of generating a design and also reveal the outputs from their individual and collective design efforts openly for anyone to use (Baldwin and von Hippel, 2011). In such projects, some partners (e.g. customers who will be users of the product), benefit directly from cooperation like learning, entertainment, mutual interest or the possibility to solve problems. As part of the indirect benefits of cooperation are reputation, knowledge sharing and networking (Baldwin and von Hippel, 2011). Radical innovation presents higher levels of uncertainty than incremental innovations due mainly to the incorporation to develop new technologies. They often require new expensive software or hardware that can be obtained through open source collaboration.. However, open source collaboration also enables the development of incremental innovations, for example through using existing, relatively standardized resources to ascertain potential areas of improvement in existing products (Song and Thieme, 2009).

\section{Research Method}

The research was carried out from January 2018 to April 2018 in Poland, using a questionnaire sent to research entities in a traditional and electronic way. The questionnaire was developed based on a 5-point Likert scale. The aim of the study was to determine the type of relations, among others, in terms of their width and depth and measures used in the studies of (Chesbrough and Vanhaverbeke, 2006) which were established during the process of innovation development by organizations operating on the Polish market. The survey consisted of 90 items and 3 metrics questions. The first part concerned the duration and length of relations with partners involved in the process of generating innovation. The respondents were to determine what kind of relationship is more valuable depending on the type of innovation being developed (radical or incremental) and to indicate the degree of involvement of partners in the various stages of the process of innovation development (searching for ideas, planning and development of innovations, testing and starting of production and sales). In the second part of the questionnaire, questions were asked about the factors that ensure success in cooperation (taking into account the type of innovation).

Deep inter-organizational relations enable organizations to use existing knowledge and resources in the innovation process based on trust in the partners. However, broad connections support the search for 
new technologies, ideas, inspirations and outlets (Albano, 2018). Open innovations bring benefits in building relations that are both broad and deep, and help find the right balance between these relations (Albano, 2018).

The obtained sample consists of 105 companies of various sizes from various sectors of the economy in accordance with the direction of their business, identifying themselves as innovative, selected randomly. Due to the size of the sample, the test results should be treated as a kind of pilot study. The innovativeness of organizations was determined based on the subjective opinion of respondents. The questionnaire was addressed to the owner of the company and the management.

\section{Research Results}

The sample was dominated by micro and small organizations employing up to 50 people (59\% of the sample), operating on the market from one year to nine years ( $38 \%$ of the sample). Half of the surveyed small and micro organizations operate primarily on the domestic market, dealing with commercial activities $(2 / 5$ of the sample).

The relational potential of the surveyed entities was determined due to the type of innovations developed by the organization. Therefore, radical and incremental innovations will be analyzed separately. The inter-organizational relations established by organizations to develop and implement incremental innovations are shown in Figure 1.

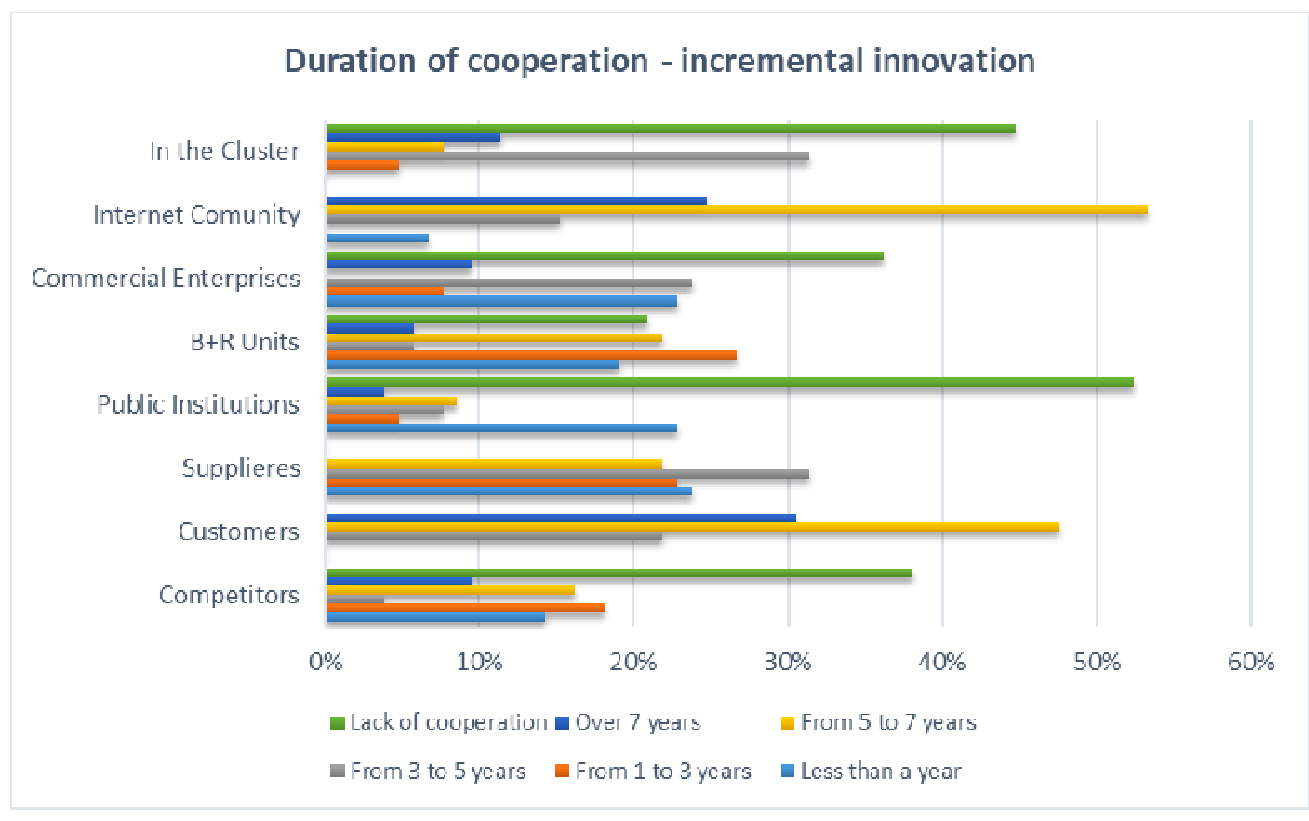

Fig. 1: Average duration of cooperation in incremental innovation

Source: own elaboration.

As shown in Fig. 1., the relational potential of organizations is diversified and includes various relations with various entities. In this case, organizations use the full range of opportunities to cooperate with the environment (wide cooperation carried out by almost $98 \%$ of the research sample). The surveyed organizations cooperate with the Internet community for the longest period of time, the average duration of the relation has been defined by more than half of the surveyed entities 
as 5-7 years. In second place (in terms of length of cooperation) is the relationship with clients $(48 \%$ of responses - for $5-7$ years). Medium-term relations are also established by organizations with suppliers (equipment, materials, components or software) and in a cluster (31\% of responses - for 3-5 years). Over $1 / 2$ of the surveyed organizations do not engage in incremental innovation with public or government institutions. A high percentage of organizations (respectively $38 \%$ and $36 \%$ of responses) do not cooperate with competitors and commercial enterprises, consulting companies, private laboratories or private $\mathrm{R} \& \mathrm{D}$ institutions.

The length of cooperation in the development and implementation of radical innovations is shown in Figure 2.

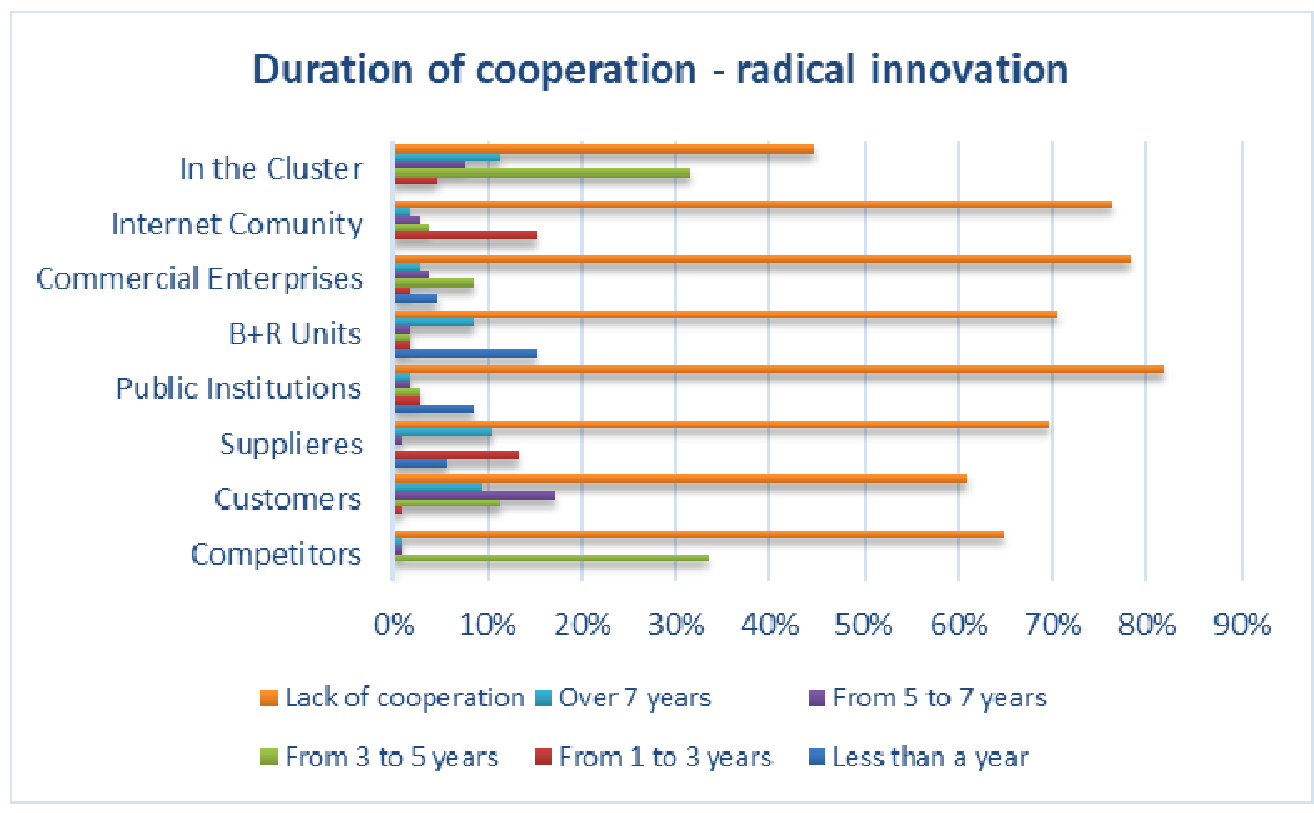

Fig. 2: Average duration of cooperation in radial innovation

Source: own elaboration

In the case of radical innovation development and implementation, 95\% of surveyed organizations use differentiated sources. In terms of radical innovations, the depth of the relation with the chosen source is the most important. 33\% of the surveyed entities indicated that the longest-lasting relations are established with competitors (from 3 to 5 years), the second place was indicated for cooperation in the cluster (also from 3 to 5 years) and with clients, established on an average from 5 to 7 years. Approximately $4 / 5$ of surveyed organizations do not establish relations with public and government institutions, private laboratories and the internet community.

The source of knowledge, inspiration or technology used by organizations depends, to a large extent, on the stage of the innovation process. These relations are shown in Figure 3. 


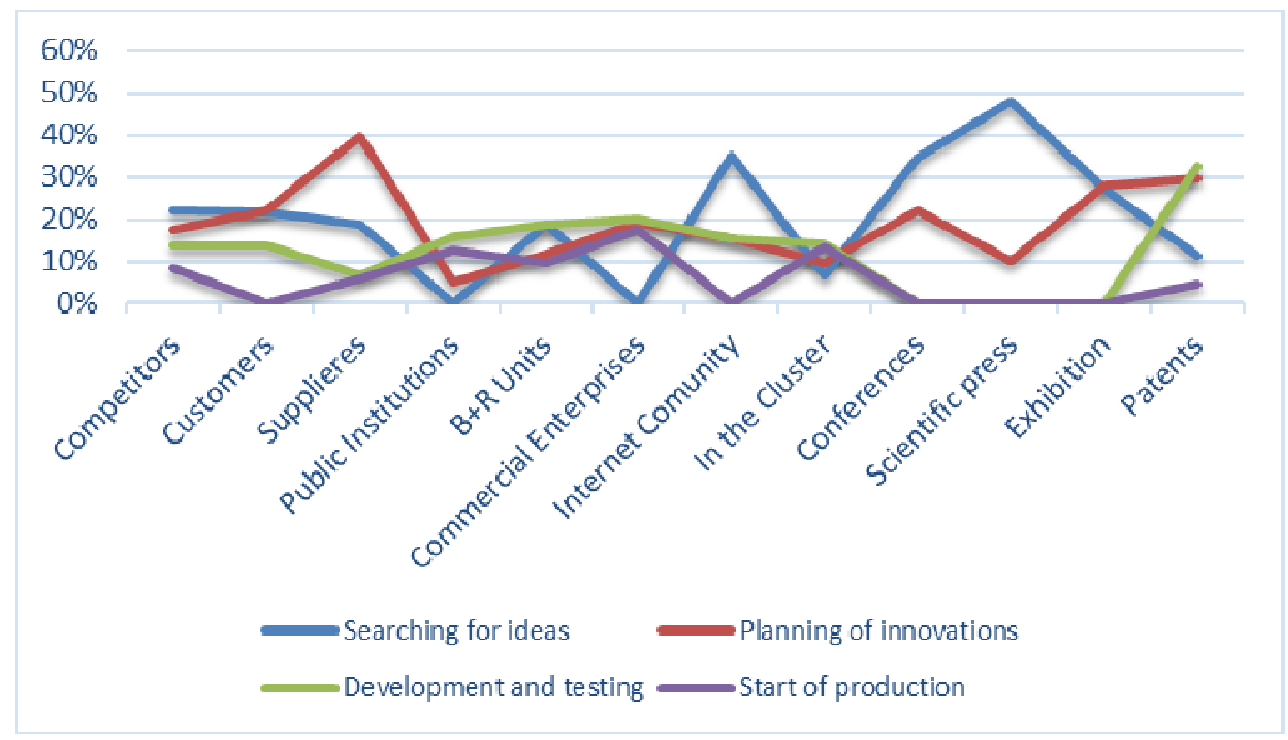

Fig. 3: The relation between the innovation stage and the source of knowledge

Source: own elaboration

At the stage of searching for an idea for innovation (including analysis of the market, customers' needs, technical options), surveyed organizations look for knowledge in the scientific and technical press, available databases $(48 \%$ of responses) and at professional conferences and meetings (35\% of responses). In addition, $36 \%$ of them cooperate at this stage with the Internet community as well as clients and competitors (about 22\% of the sample). At the stage of innovations planning (concept testing, acquisition of technology, preparation of a technology implementation plan), 2/5 attempts establish relations with suppliers and $1 / 5$ of them with consumers. Almost $30 \%$ of the research sample acquires knowledge also at trade fairs and exhibitions. In the development and testing phase (prototype construction, fixing prices, market forecasts), organizations focus on patents (32\% of them) and purchase of expertise from private laboratories or consulting companies $(20 \%$ of responses). At the moment of commencement of production and sales, the majority of organizations use the knowledge and experience of private consulting companies, private $\mathrm{R} \& \mathrm{D}$ companies and public or governmental institutions (about $1 / 5$ of responses). In addition, about $20 \%$ of them use the opportunities offered by participation in the cluster.

The last analyzed element was intended to determine the most important factor of successful cooperation with the environment - Fig. 4. In the case of developing radical innovations, the surveyed organizations indicate that the most important factor for successful cooperation is the use of formal solutions securing the relation in the form of agreements and other regulations $167 \%$ of surveyed entities in case of radical innovation and $33 \%$ of surveyed entities in case of incremental innovations). In addition, $70 \%$ of entities believe that it is necessary to set a common budget $(30 \%$ of responses for incremental innovations) and mutual trust (59\% for radical innovations and $40 \%$ for incremental innovations). 


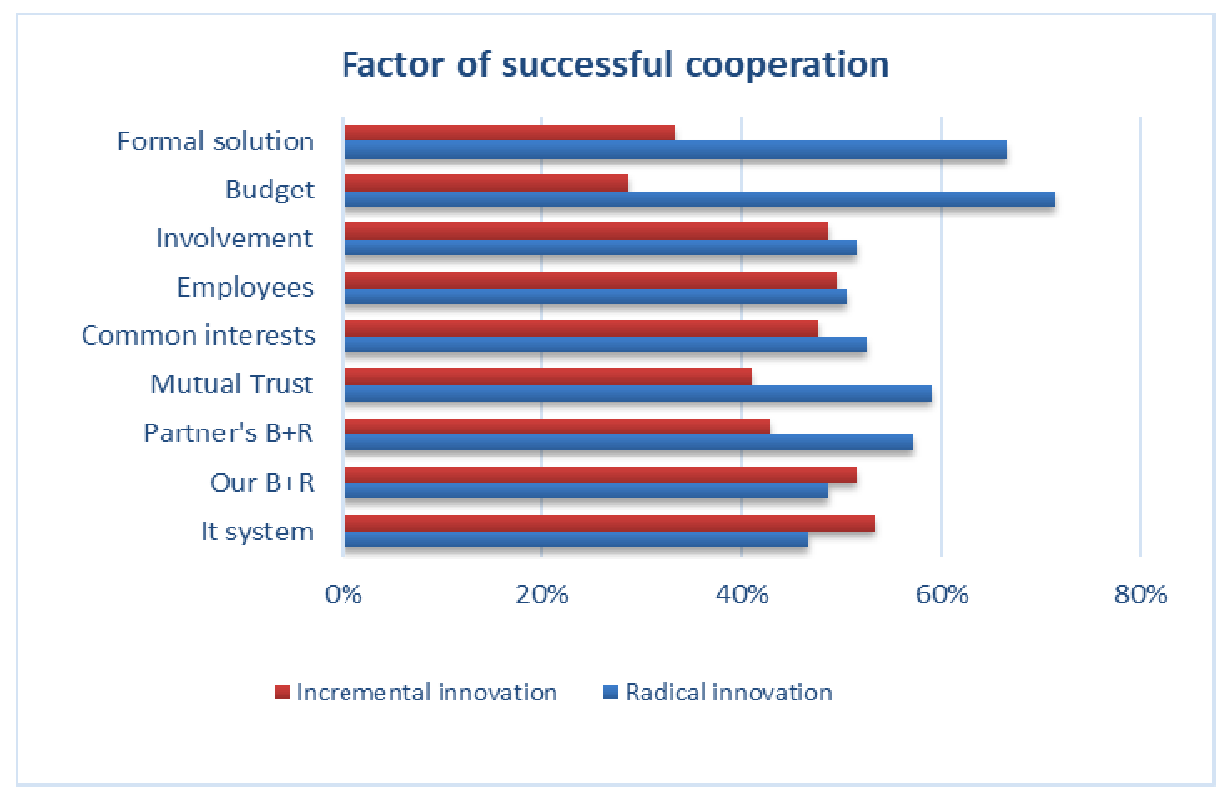

Fig. 4: The most important factor for successful cooperation

Source own elaboration

Organizations generating incremental innovations indicate that the most important is the efficient IT system and own R\&D department $\quad(53 \%$ and $51 \%$ respectively for incremental innovation, $47 \%$ and $49 \%$ for radical innovations).

\section{Conclusion}

There are many determinants of organizational level of innovations (Zimmer and Walecka-Jankowska, 2018; WaleckaJankowska and Zimmer, 2017; WaleckaJankowska, 2015). However crucial to achieving a competitive position and raising the level of innovation is cooperation (Zakrzewska-Bielawska, 2016). Open innovations focus, to a large extent, on the streams of influence and the flows of knowledge, technology and ideas to/from the organization. The dispersal of the innovation process requires the establishment of many different organizational relations, and using knowledge acquired externally together with knowledge generated inside the organization.
Enterprises that want to establish cooperation should take into account the following factors:

1. type of knowledge source

2. type of innovation being developed;

3. resources and capabilities of the enterprise itself.

Research conducted among organizations operating on the Polish market indicates that entities that define themselves as innovative ones, establish a very broad relations with the environment (use many sources of knowledge, technology and ideas). However, among the studied sample, there is no significant difference in the range of sources used, taking into account the type of innovations developed. $98 \%$ of organizations developing incremental innovations and $95 \%$ of organizations implementing radical innovations use all sources of innovation indicated in the questionnaire. Therefore, it does not confirm the view from literature research, indicating that radical innovations require a narrower and at the same time deeper range 
of sources of knowledge. The analyzed results show that deeper cooperation (measured by the duration of the relation) is established by organizations developing incremental innovations (especially with the Internet community - 53\% of responses and consumers - $48 \%$ of responses). This may be due to the fact that radical innovations (new products or services developed on the basis of new technology) are carried out relatively rarely, due to the need of accumulating high capital and a high risk of implementation. Organizations from the examined sample establish inter-organizational relations, primarily at the stage of seeking inspiration for innovation (22\% of responses) and innovation planning (19\% of responses). Only $5 \%$ of organizations use cooperation with the environment during the start of production and sales. Analysis of the key factors ensuring success in cooperation has demonstrated significant differences between organizations generating radical and incremental innovations. Radical innovations, as those burdened with significant risk and, in the case of success, high profit, require formal security of cooperation, in the form of agreements on e.g. confidentiality of information and a shared budget. In addition, organizations establishing relations are looking for trusted partners with their own $R \& D$ departments while developing radical innovations. In the case of incremental innovations, effective IT system (Protasiewicz, 2017) proved to be the most important factor which enables the flow of information. Also, owning R\&D department is important because it helps to absorb the accumulated knowledge.

The carried out research is not free of restrictions. It should be emphasized once again that the innovativeness of organizations was determined on the basis of the subjective opinion of employees, not by quantitative measures, e.g. the number of patents or implemented new solutions. In addition, the next study should identify in detail different types of innovations due to the subject criterion, i.e. product, process, marketing and organizational innovations, not only to consider the scale of changes (radical and incremental). This is necessary because respondents often perceive innovations only in terms of changes or new products on the offer, bypassing other types of innovations. The research was carried out based on selected relation' attributes, which is why further research should be extended in this respect, for example with the criterion related to the repeatability of established relations (which would allow for more precise analysis of the depth of cooperation).

\section{References}

1. Albano, M. (2018), The Adoption Of Open Innovation Practices In Global Firms, [Online]. [13.04.2018]. Available: https://boa.unimib.it/retrieve/handle/1028 1/131541/185283/phd_unimib_742068.pdf

2. Aldrich, H. F. and Martinez, M A. (2018), Many are Called, but Few are Chosen: an Evolutionary Perspective for the Study of Entrepreneurship. [Online]. [13.04.2018]. Available:

http://www.unc.edu/ healdric/Workpaper s/WP133.pdf.

3. Baldwin, C. and von Hippel, E. (2011), 'Modeling a Paradigm Shift: From Producer Innovation to User and Open Collaborative Innovation,' Organization Science 22 (6), 1399-1417.

4. Barge-Gil, A.(2010), 'Open, Semi-Open and Closed innovators. Towards an Explanation of Degree of Openness,' Industry and Innovation 17 (6), 577-607.

5. Bercovitz, J. and Feldman, M., (2007), 'Fishing upstream: firm innovation strategy and university research alliances,' Research Policy 36 (7), 930-948.

6. Borgers, M., Zobel, A-K., Afuah, A., Almirall, E., Brunswicker, S., Dahlander, L., Frederiksen, L., Gawer, A., Gruber, M., Haefliger, S., Hagedoorn, J., Hilgers, D., Laursen, K., Mangusson, M., Majchrzak, A., McCarthy, I., Moeslein, K., Nambisan, S., Piller, F., Radzwon, A., Rossi-Lamastra, C., Sims, J. and Ter Wal, A. (2016), The open innovation research landscape: established perspectives and emerging themes across different levels of analysis, [Online], 
[08.04.2018], Available: https://www.tandfonline.com/doi/full/10.1 080/13662716.2016.1240068.

7. Chesbrough, H. (2003), The Era of Open Innovation, MITSloan Management Review 44 (3), 35-41.

8. Chesbrough, H. and Crowther, A. (2006), 'Beyond high tech: early adopters of open innovation in other industries,' $R \& D$ Management 36 (3), 229-236.

9. Chesbrough, H. and Vanhaverbeke, W. and West, J. (2006), Open Innovation: Researching a New Paradigm, Oxford University Press, Oxford.

10.Cohen, W. and Levinthal, D. (1990), 'Absorptive Capacity: A New Perspective on Learning and Innovation,' Administrative Science Quarterly 35 (1), 128-152.

11.Dahlander, L., Gann D. (2010), 'How open is innovation?,' Research Policy 39 (6), 699709.

12.De Faria, P., Lima, F. and Santos, R. (2010), 'Cooperation in innovation activities: The importance of partners,' Research Policy 39, 1082-1092.

13.Faludi, J. (2014), 'Fifty shades of innovation - from open toward user, and open collaborative forms of innovation - an overview,' Vezetéstudomány XLV (11), 3343.

14.Fontana, R., Geunab, A. and Matt, M. (2006), 'Factors affecting universityindustry $R \& D$ projects: the importance of searching, screening and signaling,' Research Policy 35 (2), 309-323.

15.Karamanos, A. G. (2012), 'Leveraging micro- and macro-structures of embeddedness in alliance networks for exploratory innovation in biotechnology,' R\&D Manage., 42 (1), 71-89.

16. Mazzola, E., Perrone, G. and Kamuriwo, D. S. (2015), 'Network embeddedness and new product development in the biopharmaceutical industry: The moderating role of open innovation flow,' J. Production Economics 160, 109-119.

17.Najafian, M. and Colabi A. M. (2014), 'Inter-organizational Relationship and Innovation: A Review of Literature,' Global Business and Management Research: An International Journal 6 (1), 52-70.

18.Obal, M., Kannan-Narasimhan, R. and Ko, G. (2016), 'Whom Should We Talk to? Investigating the Varying Roles of Internal and External Relationship Quality on Radical and Incremental Innovation Performance,' J. PROD. INNOV. MANAG. 33 (S1), 136-147.

19.Pallot, M., Trousse, B., Senach, B. and Scapin, D. (2010), Living lab research landscape: from user centred design and user experience towards user cocreation, Proceedings First European Summer School Living Labs, Paris (2010).

20.Protasiewicz, J. (2017), 'Inventorum - A recommendation system connecting business and academia,' IEEE International Conference On Systems, Man, And Cybernetics (SMC), Book Series: IEEE International Conference on Systems Man and Cybernetics Conference Proceedings, 1920-1925.

21.Soh, P. H. (2003), 'The role of networking alliances in information acquisition and its implication for new product performance,' J. Bus. Venturing 18, 727-744.

22.Song, M., and Thieme J. (2009), 'The role of suppliers in market intelligence gathering for radical and incremental innovation,' Journal of Product Innovation Management 26 (1), 43-57.

23.Sousa, C, Videira, P. and Fontes, M. (2018), The role of entrepreneurs social networks in the creation and early development of biotechnology companies. [Online]. [4.04.2018]. Available: http://citeseerx.ist.psu.edu/viewdoc/downl oad?doi=10.1.1.477.1589\&rep=rep1\&type= pdf. 
24.Stańczyk-Hugiet, E. (2013), Dynamika strategiczna w ujęciu ewolucyjnym, Wydawnictwo Uniwersytetu Ekonomicznego we Wrocławiu, Wrocław.

25.Walecka-Jankowska, K. (2015), 'Relationship between knowledge management and innovation', Social Sciences 90(4), 55-66.

26.Walecka-Jankowska, K. and Zimmer J. (2017), 'Organizational structure as an organizational innovation determinant: empirical research,' Conference proceedings of the SGEM 2017, Book 1, Modern Science. Vol. 5, Business and Management. Sofia : STEF92 Technology, 24-30 August, 2017, Albena, Bulgaria, 729-740.
27.Wojciechowski, A. (2018), Teoria innowacji. [Online]. WMARR S.A. Olsztyn. [13.04.2018]. Available: http://www.een.wmarr.olsztyn.pl/badanieinnowacyjnosci-firmy/.

28.Zakrzewska-Bielawska, A. (2016), 'Tworzenie i apropriacja wartości jako cel strategii relacyjnej przedsiębiorstwa,' Prace Naukowe Uniwersytetu Ekonomicznego We Wrocławiu 444, 609-622.

29.Zimmer, J., Walecka-Jankowska, K. and Mierzwa, D. (2018), 'The role of organizational culture in an open innovation model,' Zeszyty Naukowe Politechniki Poznańskiej. Organizacja i Zarządzanie 76, 283-293. 